\title{
CONSIDERACIONES JURÍDICAS SOBRE EL GENOMA HUMANO
}

Gladys León Salcedo C *

Conferencia pronunciada en el acto académico programado en el Auditorio Guillermo Ferguson del Hospital de San José, los días 18 y 19 de julio del año 2002, con motivo de la celebración de los 100 años de fundación de la Sociedad de Cirugía de Bogotá-Hospital de San José.

La ciencia es uno de los agentes más poderosos del cambio en una sociedad y la sociedad debe aprender a manejar estos cambios. Darryl Macer hablando de los avances de la genética, sensibiliza nuestro espíritu: «Nuestra primera reacción ante el gran avance de la ciencia en el campo de la genética debe ser de admiración. Entre mas entendamos el lenguaje y el mensaje de los genes, en los humanos y en otras criaturas, más entenderemos nuestra historia y nuestra posición en el mundo, como criaturas vivientes. La humanidad ha ganado la habilidad para adaptar el medio ambiente a sus genes. Nosotros apreciamos la universalidad del código genético y sus implicaciones en el entendimiento de nuestros orígenes biológicos».

Hay nuevas alternativas sociales, éticas y legales que se desprenden del impacto de los descubrimientos en genética. Muchas actitudes se tendrán antes de que los pueblos sean capaces de diseñar normas éticas y legales que hagan compatible la realidad científica, con la sostenibilidad de la vida y con la biodiversidad, entendida como la variedad de organismos vivientes y sus interacciones ecológicas y con el respeto a los derechos del hombre.

Científicos, creadores y usuarios de tecnología, legisladores y economistas, deberán actuar guiados por la reflexión moral acorde con estas metas. Los estados tienen la obligación de establecer parámetros legislativos consecuentes con los propósitos que anteceden. El

Jefe, Oficina Jurídica de la Sociedad de Cirugía de Bogotá-Hospital de San José. Bogotá D.C., Colombia. estado que no legisla se expone a que su territorio sea zona franca de desafueros.

Pero los acercamientos éticos y legislativos presuponen conocimientos, fundamentados en la verdad, transparencia, comprobación y rigor científico, alejados de las formas irreflexivas e irresponsables con que a veces se construye la opinión publica.

Que el hombre juega a ser Dios; que nos encontramos en las puertas de conocer al verdadero Frankenstein o a los hombres alfa y beta del Mundo Feliz de Aldoux Huxley, que los centauros poblaran la tierra; con muy poco sustento fáctico, son las expresiones del miedo a lo desconocido. Responder a estos miedos envuelve argumentación filosófica y entendimiento del conocimiento científico. Pero ningún acercamiento ético ni legislativo seria racional partiendo de dichas premisas.

Nos encontramos, ante la necesidad de explicar cambios traídos por los descubrimientos en biotecnología y biomedicina y conocer su potencialidad, posibilidades y reales peligros. Un nuevo lenguaje se nos acerca, con implicaciones económicas, éticas, filosóficas y legales.

El acceso del gobierno, de las aseguradoras, de los empleadores, a los datos de nuestro genoma, así como el problema de las patentes, exige arduas jornadas en pro de la dignidad humana, de su autonomía, de las libertades fundamentales, para que no haya discriminación dependiendo de la predisposición y condiciones genéticas de un individuo.

Es el comienzo de un largo proceso en materia de control y de información. La ignorancia de las consecuencias necesita precaución en el uso de las nuevas técnicas y esta precaución debe ser el fundamento legislativo.

El mejoramiento del nivel de la existencia, las posibilidades de la terapia génica frente a múltiples enfermedades causa del sufrimiento humano, el conocimiento de las deficiencias de nuestro código genético, son 
perspectivas muy importantes a tener en cuenta. De ahí que deba existir una protección a la investigación como consecuencia de la libertad de pensamiento y de la necesidad del progreso del saber. Las aplicaciones de la investigación sobre el genoma humano, sobre todo en el campo de la biología, la genética y la medicina, deben orientarse a aliviar el sufrimiento y mejorar la salud del individuo y de toda la humanidad.

De acuerdo con Cavalieri, la ingeniería genética ha conferido a la raza humana un poder análogo al de ciencia nuclear, para el cual no se encuentra preparada psicológica y moralmente. ¿En qué manos estará este poder? ¿En manos de los científicos o bajo el control comercial?

La relación entre los problemas y las soluciones es interactiva. El impacto potencial de los avances en biotecnología no es solamente irreversible sino que introduce mayores e impredecibles cambios en la organización global y en la distribución de la producción.

La historia de las legislaciones intentado mantener o estableciendo un orden social en la interacción entre médicos, investigadores y seres humanos es muy antigua. El código de Hammurabi (1728 a 1686 AC), el más famoso de todos los códigos de Mesopotamia; el juramento hipocrático, el código de Maimonides, las obras de Thomas Percival y de Michael Ryan; constituyen antecedentes de la preocupación del hombre a lo largo de la historia, por revestir el acercamiento al paciente, de actitudes de beneficencia, no maleficencia y solidaridad, hoy tan actuales como en las tempranas épocas de la humanidad. Más adelante se han desarrollado principios tan importantes como el de autonomía y justicia que junto con los anteriores constituyen los imperativos de conducta frente al tema de la investigación y frente al tema del genoma humano, que nos ocupa. ${ }^{1}$

El 11 de noviembre de 1997 se reunió la vigésima novena Conferencia General de la UNESCO y por unanimidad se constituyó el primer instrumento universal en el campo de la biología, estableciendo un equilibrio entre la garantía del respeto de los derechos y las libertades fundamentales y la necesidad de garantizar la libertad de la investigación. En la declaración de la UNESCO se contemplan entre otras cuestiones, las siguientes, que nos permitimos destacar:
- El genoma es la base de la unidad fundamental de la raza humana, patrimonio de la humanidad. Por naturaleza evolutivo y sometido a mutaciones, entraña posibilidades que se expresan de diferentes modos, obedeciendo al entorno social y natural de la persona, los cuales comprenden condiciones de vida, alimentación, educación y estado de salud.

- Ninguna investigación relativa al genoma humano podrá prevalecer sobre el respeto de los derechos humanos, de las libertades fundamentales y de la dignidad humana. Las investigaciones como la presentación y utilización de los resultados imponen rigor científico, prudencia, probidad intelectual e integridad y deben orientarse a aliviar el sufrimiento y mejorar la salud del individuo y de la humanidad.

- Toda persona debe tener acceso a los progresos de la biología, la genética y la medicina en materia de genoma humano.

Se prohibe expresamente:

- Cualquier práctica contraria a la dignidad humana.

- Clonación con fines de reproducción de seres humanos.

- Beneficios pecuniarios que se deriven de su estado natural.

La persona frente al genoma humano tiene derecho:

- Al reconocimiento de su dignidad e individualidad.

- A no ser objeto de discriminaciones fundadas en sus características genéticas.

- A la confidencialidad de los datos genéticos asociados con una persona identificable.

- A la reparación equitativa del daño causado cuya causalidad radique en una intervención en su genoma.

Toda investigación, tratamiento o diagnóstico con base en el genoma humano requiere:

- Protocolos de investigación sometidos a una evaluación previa de conformidad con normas nacionales e internacionales sobre la materia.

- Evaluación rigurosa de riesgos y beneficios.

- Consentimiento previolibre e informado que respete la autonomía del individuo para decidir sobre la información que desea recibir y compartir de los resultados de un examen genético y de sus consecuencias. 
Los Estados están obligados a:

- Formular las políticas sobre la investigación y el manejo del genoma humano con responsabilidad frente a las consecuencias que de él se derivan, evaluando riesgos y ventajas, previniendo los abusos, favoreciendo las condiciones intelectuales y materiales propicias para el libre ejercicio de las actividades de investigación encaminadas a identificar, prevenir y tratar las enfermedades genéticas, las enfermedades raras y las enfermedades endémicas que afectan a una parte considerable de la población mundial o aquéllas en las que interviene la genética, garantizando el respeto de los derechos humanos, las libertades fundamentales, la dignidad humana, la protección de la salud publica, las investigaciones , sobre todo.

- A respetar y promover la práctica de la solidaridad para con los individuos, familias o poblaciones particularmente expuestos a las enfermedades o discapacidades de índole genética o afectados por éstas y a fomentar la difusión internacional de los conocimientos científicos sobre el genoma humano, la diversidad humana y la investigación genética, y la cooperación científica y cultural, entre países industrializados y países en desarrollo, con el libre intercambio de conocimientos e información.

- Se deberían comprometer, además, a favorecer un debate abierto en el plano internacional que garantice la libre expresión de las distintas corrientes de pensamiento socioculturales, religiosas y filosóficas y a promover la creación de comités de ética independientes y pluralistas, encargados de apreciar las cuestiones éticas, jurídicas y sociales planteadas por las investigaciones sobre el genoma humano y sus aplicaciones.

Nuestro país no es huérfano de legislación con respecto al tema que nos ocupa. Mediante la Ley 599 del año 2000 que empezó a regir el 24 de julio de 2001 se diseñaron las primeras normas en materia penal y es así, como se sanciona con pena de prisión de uno (1) a cinco (5) años, al que manipule genes humanos alterando el genotipo, salvo que se trate de tratamiento, diagnóstico o investigación científica en el campo de la biología, la genética y la medicina, con la finalidad de aliviar el sufrimiento o mejorar la salud de la persona y de la humanidad, para el descubrimiento, identificación, prevención y tratamiento de enfermedades o discapacidades genéticas, así como las taras y endemias que afecten a una parte considerable de la población, mediando el consentimiento, libre e informado de la persona de la cual proceden los genes.

También establece el código penal un rechazo a la clonación: "El que genere seres humano idénticos por clonación o por cualquier otro procedimiento, incurrirá en prisión de dos (2) a seis (6) años.

Obviamente estas legislaciones cambiarán a medidaque la ciencia y los hombres prosigan su camino. Los niveles de inteligencia son exactamente niveles de vida. El estudio de la vida, es el estudio de las posibilidades.

Como lo decía Stephen Jay Gould, biólogo recientemente fallecido, en su magnifica obra «Qué es la Vida: La humanidad no es como un organismo pluricelular en el que cada célula se debe por ley genética al bien común de la colectividad celular. La información cultural no es heredada por el individuo, como tampoco lo es la conducta socialmente aceptable. Después de milenios de evolución cultural, la gente sigue haciéndose la guerra, y con la misma crueldad de siempre. Nos engañamos a nosotros mismos si creemos que la conducta socialmente aceptable es algo natural... Las ideologías no pueden reemplazar la razón. Nada cambiará si no basamos nuestras decisiones en la razón, aceptando la humanidad como un imperativo moral.»

El futuro de la humanidad está en comportamientos y actitudes compatibles con la Bioética: la pregunta es si nosotros tenemos el conocimiento y la sabiduría para alterar exitosamente las manifestaciones de vida que nos han acompañado, después de un largo periodo de adaptación, sin crear catástrofes o desastres ecológicos.

Vivimos en el mundo que construyeron los hombres del ayer y estamos creando el mundo que habitarán los hombres del mañana, de ahí la responsabilidad que se asume frente a la lógica de lo viviente, al camino de la evolución y de la supervivencia.

\section{Lecturas recomendadas}

1. Macer DR. Shapping Genes. Ethics, Law an Science of Using Genetics in Medicine and Agriculture. Eubios Ethics Institute 1990.

2. Código Penal Colombiano articulos 132 y 133.

'Thomas Percibal (1740-1804) 1742 hizo un código de reglas para regular y gobernar los médicos del Hospital de Manchester - 1800 -1841 produjo un manual de ética y ley en medicina. 